\title{
Enzyme activity of topsoil layer on reclaimed and unreclaimed post-mining sites
}

\author{
Petr Heděnec a, b, c, Olga Vindušková b, Jaroslav Kukla ${ }^{b}$, \\ Jaroslav Šnajdr d, Petr Baldrian d and Jan Frouz a, b \\ a Institute of Soil Biology+SoWa RI, Na Sádkách 7, České Budějovice, 370 05, Czech Republic; \\ petr.hedenec@natur.cuni.cz \\ b Institute for Environmental Studies+SoWa RI, Faculty of Science, Charles University, Benátská 2, \\ Prague 2, 128 44, Czech Republic \\ c Department of Ecology, Faculty of Science, Charles University, Viničná 7, Prague 2, 128 44, \\ Czech Republic \\ d Laboratory of Environmental Microbiology, Institute of Microbiology of the ASCR, Vídeňská \\ 1083, 14220 Prague 4, Czech Republic
}

Address correspondence and requests for materials to Petr Heděnec

Citation: Heděnec, P., Vindušková, O., Kukla, J. Šnajdr, J., Baldrian, P. \& Frouz, J. 2017. Enzyme activity of topsoil layer on reclaimed and unreclaimed post-mining sites. Bio. Comm. 62(1): 19-25. doi: 10.21638/11701/spbu03.2017.103

Author's information: Petr Heděnec, $\mathrm{PhD}$ Postdoctoral Researcher, orcid.org/0000-0002-94258525; Olga Vindušková, MSc, PhD student, https:// www.researchgate.net/profile/Olga Vinduskova; Jaroslav Kukla, MSc, PhD student; Jaroslav Šnajdr, PhD, Postdoctoral Researcher; Petr Baldrian, $\mathrm{PhD}$, Associated Professor, orcid.org/0000-00028983-2721; Jan Frouz, PhD, Full-professor, orcid. org/0000-0002-0908-8606

Manuscript Editor: Evgeny Abakumov, Saint Petersburg State University, Russia

Received: July 31, 2016;

Revised: January 29, 2017;

Accepted: February 15, 2017;

Copyright: @ 2017 Heděnec et al. This is an openaccess article distributed under the terms of the License Agreement with Saint Petersburg State University, which permits to the authors unrestricted distribution and self-archiving free of charge.

Funding: This study was supported by the Research Centre grant LC06066 and by grant from Czech Science Foundation P504/12/1288.

Competing interests: The authors have declared that no competing interests exist.

\section{Abstract}

Topsoil layer contains various components of soil organic matter such as branches, leaves, bark, or metabolites and residues of soil biota. Soil organic matter (SOM) in forest ecosystems consists mostly of lignin, cellulose, chitin and other hydrocarbons. These compounds are decomposed mainly by soil fungi which produce extracellular enzymes to decompose wide range of organic residues. These enzymes may alter nutrient cycling and change soil properties such as water retention capacity, ion exchange capacity, formation of soil microstructure, soil microbial respiration, etc. In this study, we studied enzyme activity in the topsoil layer of postmining spoil heaps near Sokolov, Czech Republic. We investigated the effect of the following factors and their combinations on enzyme activity: i) dominant vegetation, ii) time of sampling, iii) reclamation, and iv) soil macrofauna.

We measured enzyme activity in plastic mesocosms with autochthonous litter deposited on reclaimed and unreclaimed post-mining sites. We used mesocosms accessible for macrofauna (mesh size $>2 \mathrm{~mm}$ ) and mesocosms inaccessible for macrofauna (mesh size $<2 \mathrm{~mm}$ ). Under laboratory conditions, we measured enzyme activity (laccase, oxidase, peroxidase, Mn-peroxidase, alkaline phosphatase, acid phosphatase, endoglucanase, xylanase, cellobiohydrolase, glucosidase, xylosidase and chitinase) using buffer extraction method followed by spectrophotometric assay. We did not find any statistically significant difference between mesocosms accessible and inaccessible for fauna. However, we found significant effect of time of sampling on enzyme activity. Our results showed significant difference between reclaimed and unreclaimed post-mining sites. Reclaimed sites showed significantly higher enzyme activity than unreclaimed sites.

Keywords: enzyme assay, microbial activity, litterbag, macrofauna, soil fauna

\section{Introduction}

Soil fungi are widely distributed decomposers of soil organic matter in forest soils (Lavelle et al., 1997; Tedersoo et al., 2014; Wardle and Lindahl, 2014). Cellulose is one of the most important polymeric substances in cell walls and most abundant polysaccharide on Earth (Allison and Vitousek, 2005; Valášková et al., 2007). Soil fungi produce large mycelial networks which grow throughout the litter layer and thus play important role in nutrient transport (Boddy, 1999). Extracellular enzymes such as cellulase released from mycelial networks are responsible for decomposition of plant cell walls and mineralization of complex organic compounds into simple molecules (sugars, amino acids, phosphates) which can serve as food resource for other soil biota (Bardgett and van der Putten, 2014; Pietsch et al., 
2014; Wardle and Lindahl, 2014). These enzymes are initial agents for nutrient cycling. Activity of extracellular enzymes is widely used as an indicator of soil quality (Baldrian et al., 2008; Šnajdr et al., 2008; Voř́šková et al., 2011). Higher activity of extracellular enzymes is associated with regions of high nutrient turnover and primary productivity as well (Bandick and Dick, 1999).

Interaction between soil fungi and other soil microorganisms is very important for enzyme production and its physiological activity. Competitive interactions between fungi and other soil biota (bacteria, actinomycetes) cause lysis of hyphal cells and thus release of nutrients (Wells and Boddy, 2002). In particular, fungifeeding soil fauna consume mycelia and thus release nutrients into the soil where they become accessible for other soil organisms (Bardgett and Cook, 1998). The enzyme activity of the upper soil layer is mainly influenced by selective grazing, selective digestion, selective distribution of microflora, fragmentation of litter, changes of $\mathrm{pH}$ and formation of soil aggregates (Lavelle, 2000; Caldwell, 2005; Heděnec et al., 2013; Frouz et al., 2015).

In this short contribution, we focused on the role of interactions between soil fauna and soil microbiota on reclaimed and unreclaimed post-mining sites near Sokolov city (Czech Republic). Open cast lignite mining causes massive destroying of native ecosystems and excavation of large amount of spoil material which is then deposited on spoil heaps (Helingerova et al., 2010). Mining areas and heaps cover over 6000 ha in the Sokolov lignite mining district. Spoil material has initially very low biological activity (Frouz et al., 2001; Helingerova et al., 2010). Soil formation connected with increased biological activity of spoil material colonized by microbes is the basic precondition for ecosystem restoration on spoil heaps (Bradshaw, 1997).

Our research was aimed at the following questions: (i) How does dominant vegetation affect enzyme activity in the topsoil layer? (ii) How is enzyme activity affected by time of sampling? (iii) How does enzyme activity differ in reclaimed and unreclaimed sites? And finally: (iv) How does soil macrofauna affect enzyme activity?

\section{Materials and methods}

\section{STUDY SITES AND SAMPLING}

For this experiment, we used a system of plastic mesocosms filled with $10 \mathrm{~g}$ of autochthonous litter. Mesocosms were deposited on reclaimed and unreclaimed post-mining sites in Velká podkrušnohorská spoil heap (Fig. 1). We chose two experimental sites. The first site (also known under code II) is a 20-year-old unreclaimed post-mining site colonized by Salix caprea, Populus tremula and Betula pendula. The second site (code V2) is a 30-year-old

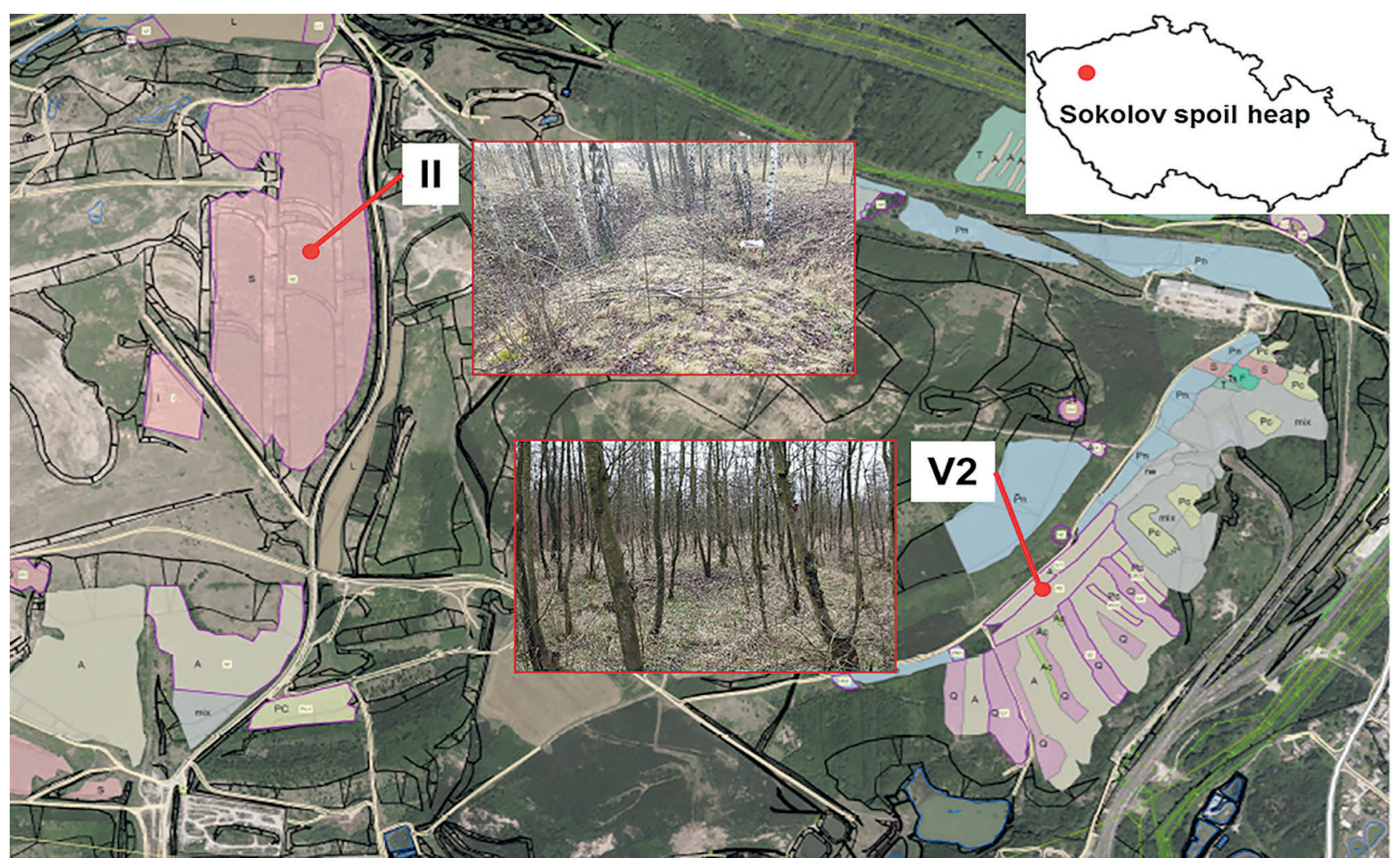

Fig. 1. Map of sampling sites on spoil heap. 


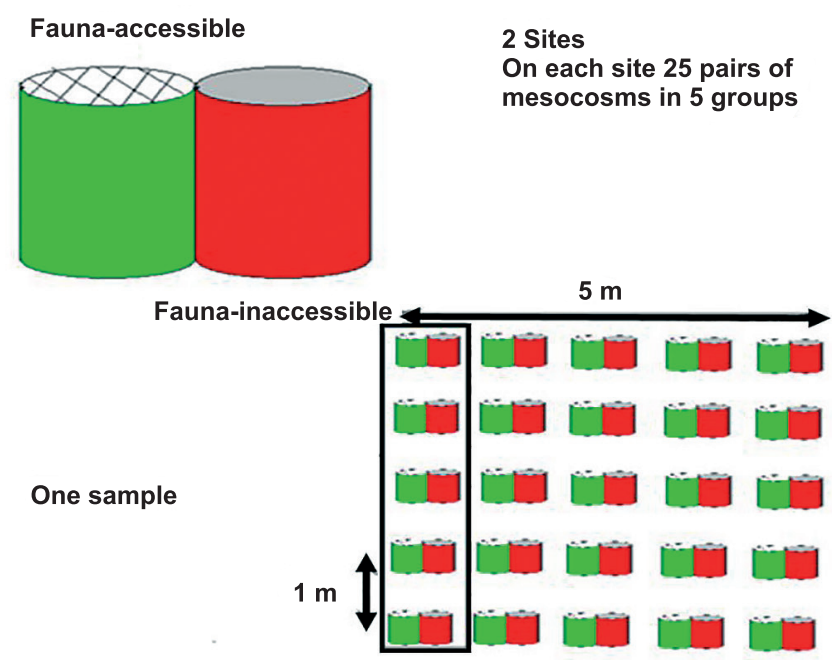

Fig. 2. Description of mesocosms and experimental design of field experiment.

reclaimed post-mining site planted with Alnus glutinosa and Alnus incana. We used plastic cylindrical mesocosms (10 cm high, $5 \mathrm{~cm}$ in diameter, Fig. 2) closed at each end by a net with different mesh size. Mesocosms accessible to fauna were closed by net with mesh size more than $2 \mathrm{~mm}$ while inaccessible mesocosms were closed by net with mesh size less than $2 \mathrm{~mm}$. Each mesocosm was filled with $10 \mathrm{~g}$ of dried autochthonous litter shaken from trees grown on examined experimental sites. We designed two fields on each site with 25 pairs of randomly distributed mesocosms in five groups (Fig. 2). Distance between pairs of mesocosms was one meter. The experiment was launched in October 2007 and sampling was conducted from February 2008 to September 2008 (Feb 2008, Apr 2008 and Sept 2008). In total, five accessible and inaccessible mesocosms were taken during one sampling campaign.

\section{ENZYME EXTRACTION AND ASSAY}

Samples from each mesocosm were purified, desalted and assayed under laboratory conditions (Šnajdr et al., 2008). Homogenized samples of autochtonous litter were extracted at $4^{\circ} \mathrm{C}$ for $2 \mathrm{~h}$ on an orbital shaker (100 rpm) with $100 \mathrm{mM}$ phosphate buffer, pH 7 (16:1 w/w), filtered through Whatman 5 filter paper and desalted using PD-10 desalting columns (Pharmacia, Sweden) to remove inhibitory small-molecular-mass compounds (Baldrian et al., 2008). The desalted samples were kept at $-18^{\circ} \mathrm{C}$ until enzyme activity assay (Šnajdr et al., 2008).

\section{Laccase (IUBMB Enzyme Nomenclature,} EC 1.10.3.2) activity was measured using monitoring the oxidation of ABTS (2,20-azinobis-3-ethylbenzothiazoline-6-sulfonic acid) in citrate-phosphate $(100 \mathrm{mM}$ citrate, $200 \mathrm{mM}$ phosphate) buffer ( $\mathrm{pH} \mathrm{5.0)}$ at $420 \mathrm{~nm}$ (Šnajdr et al., 2008).
Mn-peroxidase (MnP, EC 1.11.1.13) was measured using succinate-lactate buffer $(100 \mathrm{mM}, \mathrm{pH} 4.5)$ (Šnajdr et al., 2008). The MBTH (3-methyl-2-benzothiazolinone hydrazone) and DMAB (3,3-dimethylaminobenzoic acid) were oxidatively coupled by the enzymes, and the resulted purple indamine dye was detected spectrophotometrically at $595 \mathrm{~nm}$. The results were corrected by comparison with samples without manganese (for $\mathrm{MnP}$ ) - the addition of manganese sulfate was substituted by an equimolar amount of ethylenediaminetetraacetate (EDTA). One unit of enzyme activity was defined as the amount of enzyme forming $1 \mathrm{mmol}$ of reaction product per min (Šnajdr et al., 2008).

Endoglucanase (EC 3.2.1.4) and xylanase (EC 3.2.1.8) were measured with azo-dyed carbohydrate substrates (carboxymethyl cellulose and birchwood xylan) according to manufacturer's instructions (Megazyme, Ireland). The reaction mixture contained $0.2 \mathrm{~mL}$ of $2 \%$ dyed substrate in $200 \mathrm{mM}$ sodium acetate buffer ( $\mathrm{pH} 5.0$ ), and $0.2 \mathrm{~mL}$ sample. The reaction mixture was incubated at $40^{\circ} \mathrm{C}$ for $60 \mathrm{~min}$ and the reaction was stopped by adding $1 \mathrm{~mL}$ of ethanol followed by $10 \mathrm{~s}$ vortexing and $10 \mathrm{~min}$ centrifugation (10000 rpm) (Valášková et al., 2007). The amount of released dye was measured at $595 \mathrm{~nm}$ and the enzyme activity was calculated according to standard curves correlating the dye release with the release of reducing sugars. One unit of enzyme activity was defined as the amount of enzyme releasing $1 \mathrm{mmol}$ of reducing sugars per min (Šnajdr et al., 2008).

Cellobiohydrolase (EC 3.2.1.91) was assayed in microplates using p-nitrophenyl-beta-D-cellobioside (PNPC). The reaction mixture contained $0.16 \mathrm{~mL}$ of $1.2 \mathrm{mM}$ PNPC in $50 \mathrm{mM}$ sodium acetate buffer ( $\mathrm{pH} 5.0$ ) and $0.04 \mathrm{~mL}$ sample. Reaction mixtures were incubated at $40^{\circ} \mathrm{C}$ for $90-120 \mathrm{~min}$. The reaction was stopped by adding $0.1 \mathrm{~mL}$ of $0.5 \mathrm{M}$ sodium carbonate, and absorbance was read at $400 \mathrm{~nm}$ (Valášková et al., 2007; Šnajdr et al., 2008).

Glucosidase (EC 3.2.1.21), xylosidase (EC 3.2.1.37) and chitinase (EC 3.2.1.52) were assayed using p-nitrophenyl-b-D-glucoside, $\mathrm{p}$-nitrophenyl-b-D-xyloside and p-nitrophenyl-N-acetyl-b-D-glucosaminide, respectively, using the same method (Valášková et al., 2007).

Phosphatases (EC 3.1.3.1) were assayed using $2 \mathrm{~g}$ $\mathrm{L}^{-1} \mathrm{p}$-nitrophenylphosphate in $50 \mathrm{mM}$ sodium acetate buffer ( $\mathrm{pH}$ 5.0) as described previously. One unit of enzyme activity was defined as the amount of enzyme releasing $1 \mathrm{mmol}$ of p-nitrophenol per min (Šnajdr et al., 2008).

All spectrophotometric measurements were done in a microplate reader (Sunrise, Tecan) on a UV-VIS spectrophotometer (Lambda 11, Perkin-Elmer) and expressed per g dry mass of autochtonous litter. 


\section{STATISTICAL ANALYSIS}

All obtained data were subjected to Shapiro test to check data normality. Results of our study were analyzed using multivariate methods in statistical program Canoco 4.0 (Lepš and Hadincová, 1992). We used RDA multivariate method for statistical analysis of enzyme activity for different treatments. Time of sampling, accessibility for fauna and reclamation were used as explanatory variables. Monte-Carlo permutation test was used to check the statistical significance of particular environmental variables on the enzyme activity.

\section{Results}

Results after the application of multivariate data analysis (RDA) and Monte-Carlo permutation showed (Table) marginal effect of fauna-accessible mesocosms on enzyme activity $(\mathrm{P}=0.8)$. The enzyme activity of fauna-in-

\section{Average enzyme activities $(\mathrm{mU} / \mathrm{g})$ in fauna-accessible and fauna-inaccessible mesocosms deposited on reclaimed and unreclaimed post-mining sites on spoil heap near city Sokolov (Czech Republic)}

\begin{tabular}{|c|c|c|c|c|}
\hline Enzymes & \multicolumn{2}{|c|}{$\begin{array}{c}\text { Fauna } \\
\text { accessible } \pm S D\end{array}$} & \multicolumn{2}{|c|}{$\begin{array}{c}\text { Fauna } \\
\text { inaccessible } \pm S D\end{array}$} \\
\hline Laccase & 39.33 & \pm 71.2 & 32.34 & \pm 23.4 \\
\hline Mn-peroxidase & 35.49 & \pm 54.4 & 35.2 & \pm 23.3 \\
\hline Peroxidase & 69.1 & \pm 125.5 & 63.79 & \pm 117.5 \\
\hline Oxidase & 40.86 & \pm 59.9 & 41.57 & \pm 62.4 \\
\hline CMCase & 63.44 & \pm 53.3 & 61.57 & \pm 31.5 \\
\hline Xylanase & 138.99 & \pm 254.8 & 227.89 & \pm 132.6 \\
\hline B-glucosidase & 814.66 & \pm 1115.1 & 789.53 & \pm 990.2 \\
\hline Endoglucanase & 204.38 & \pm 278.9 & 308.46 & \pm 299.4 \\
\hline Xylosidase & 127.52 & \pm 165.6 & 144.35 & \pm 156.5 \\
\hline Chitinase & 230.6 & \pm 257.5 & 222.32 & \pm 263.5 \\
\hline A-phosphatase & 1421.81 & \pm 1932 & 1013.45 & \pm 1200.5 \\
\hline \multirow[t]{2}{*}{ B-phosphatase } & 383.64 & \pm 402.3 & 201.44 & \pm 120.5 \\
\hline & \multicolumn{2}{|c|}{ Reclaimed $\pm S D$} & \multicolumn{2}{|c|}{ Unreclaimed $\pm S D$} \\
\hline Laccase & 56.15 & \pm 48 & 55.0 & \pm 40.1 \\
\hline Mn peroxidase & 66.15 & \pm 78.5 & 25.85 & \pm 51.5 \\
\hline Peroxidase & 45.27 & \pm 42.2 & 25.72 & \pm 41.1 \\
\hline Oxidase & 77.2 & \pm 121.5 & 60.1 & \pm 122.3 \\
\hline CMCase & 49.3 & \pm 44.7 & 32.4 & \pm 43.8 \\
\hline Xylanase & 95.48 & \pm 41.4 & 31.4 & \pm 15.2 \\
\hline B-glucosidase & 234.19 & \pm 325.5 & 43.79 & \pm 14.3 \\
\hline Endoglucanase & 1223.28 & \pm 730.1 & 406.04 & \pm 371.5 \\
\hline Xylosidase & 352.56 & \pm 124.5 & 56.18 & \pm 44.3 \\
\hline Chitinase & 227.62 & \pm 97.8 & 27.41 & \pm 28.3 \\
\hline A-phosphatase & 2115.76 & \pm 1409.3 & 727.86 & \pm 955.9 \\
\hline \multirow[t]{2}{*}{ B-phosphatase } & 546.32 & \pm 295.5 & 220.96 & \pm 167.6 \\
\hline & \multicolumn{2}{|c|}{ Winter $08 \pm$ SD } & \multicolumn{2}{|c|}{ Spring $08 \pm$ SD } \\
\hline Laccase & 90.9 & \pm 84.1 & 32.05 & \pm 52.1 \\
\hline Mn peroxidase & 75.27 & \pm 63.6 & 11.54 & \pm 19.9 \\
\hline Peroxidase & 168.78 & \pm 144.1 & 4.52 & \pm 8.6 \\
\hline Oxidase & 83.21 & \pm 71.6 & 12.15 & \pm 16.7 \\
\hline
\end{tabular}

\begin{tabular}{|c|c|c|c|c|}
\hline CMCase & 95.51 & \pm 54.3 & 22.07 & \pm 11.5 \\
\hline Xylanase & 72.67 & \pm 65.9 & 40.63 & \pm 14.3 \\
\hline B-glucosidase & 1774.47 & \pm 1185.6 & 125.6 & \pm 29.3 \\
\hline Endoglucanase & 409.02 & \pm 327.3 & 31.07 & \pm 21.4 \\
\hline Xylosidase & 232.19 & \pm 189.3 & 22.98 & \pm 34.4 \\
\hline Chitinase & 440.88 & \pm 272.8 & 42.6 & \pm 16.9 \\
\hline A-phosphatase & 3317.08 & \pm 1693.7 & 119.53 & \pm 63.8 \\
\hline \multirow{2}{*}{ B-phosphatase } & 752.98 & \pm 392.1 & 102.66 & \pm 28.6 \\
\hline & \multicolumn{2}{|c|}{ Summer 08 \pm SD } & & \\
\hline Laccase & 0.08 & \pm 0.1 & & \\
\hline Mn peroxidase & 6.41 & \pm 7.5 & & \\
\hline Peroxidase & 0.76 & \pm 1.3 & & \\
\hline Oxidase & 13.07 & \pm 16.4 & & \\
\hline CMCase & 62.08 & \pm 43.1 & & \\
\hline Xylanase & 325.79 & \pm 386.3 & & \\
\hline B-glucosidase & 223.97 & \pm 103.9 & & \\
\hline Endoglucase & 104.82 & \pm 84.8 & & \\
\hline Xylosidase & 92.48 & \pm 105.4 & & \\
\hline Chitinase & 138.23 & \pm 87.1 & & \\
\hline A-phosphatase & 197.05 & \pm 79.5 & & \\
\hline B-phosphatase & 172.17 & \pm 34.6 & & \\
\hline $\begin{array}{c}\text { Explanatory } \\
\text { variables }\end{array}$ & P-value & \multicolumn{2}{|c|}{$\begin{array}{c}\% \text { of data } \\
\text { variability }\end{array}$} & F-value \\
\hline Fauna & ns & 32 & & 1.1 \\
\hline Reclamation & 0.001 & 48.5 & & 14.4 \\
\hline Sampling time & 0.002 & 39.5 & & 10.12 \\
\hline
\end{tabular}

accessible mesocosms was not statistically significantly different from fauna-accessible mesocosms (Figs 3, 4). Both inaccessible as well as accessible mesocosms placed in the reclaimed sites showed significantly higher $(P=0.002)$ enzyme activity than those mesocosms placed in unreclaimed sites (Figs 3, 4).

Figures 3 and 4 show activity of extracellular enzymes (laccase, oxidase, peroxidase, Mn-peroxidase, alkaline phosphatase, acid phosphatase, endoglucanase, endo-xylanase, cellobiohydrolase, glucosidase, xylosidase and chitinase) as influenced by reclamation (Fig. 3) and accessibility of mesocosms for soil macrofauna (Figs 3, 4).

We found a statistically significant effect of the time of sampling on enzyme activity (Table).The activity of enzymes in mesocosms were statistically significantly different $(\mathrm{P}=0.002)$ at the various sampling time (from Feb 2008 to Sep 2008). We found variable enzyme activity among individual samples. We found significant effect of restoration on the activity of enzymes (laccase, oxidase, peroxidase, Mn-peroxidase, alkaline phosphatase, acid phosphatase, endoglucanase, endoxylanase, cellobiohydrolase, glucosidase, xylosidase and chitinase) in mesocosms deposited on reclaimed and unreclaimed sites.

The results subjected to multivariate data analysis (RDA) with the covariates reveal that the reclaimed area showed significantly higher (0.0012) enzyme activity than mesocosms distributed on unreclaimed site (Fig. 5). 
Fig. 3. The effect of soil fauna on the enzymatic activity of litter in mesocosms deposited on reclaimed and unreclaimed post mining sites. Monte-Carlo permutation test $(F=1.004, P$-value $=0.8)$ for the fauna, $(F=5.456, P=0.002)$ for the restoration effect.

Fig. 4. The effect of fauna accessibility on the activity of extracellular enzymes. Explained $39.5 \%$ of data variability. Monte-Carlo permutation test $(\mathrm{F}=0.456$, $\mathrm{P}=0.852$ ).

Fig. 5. Effect of restoration on enzyme activity. Monte-Carlo permutation test with faunal and seasonal effects as covariates $(\mathrm{F}=6.589$, P-value $=0.0012)$. Alder - reclaimed area, Salix - unreclaimed area. Explained $48.5 \%$ data variability.
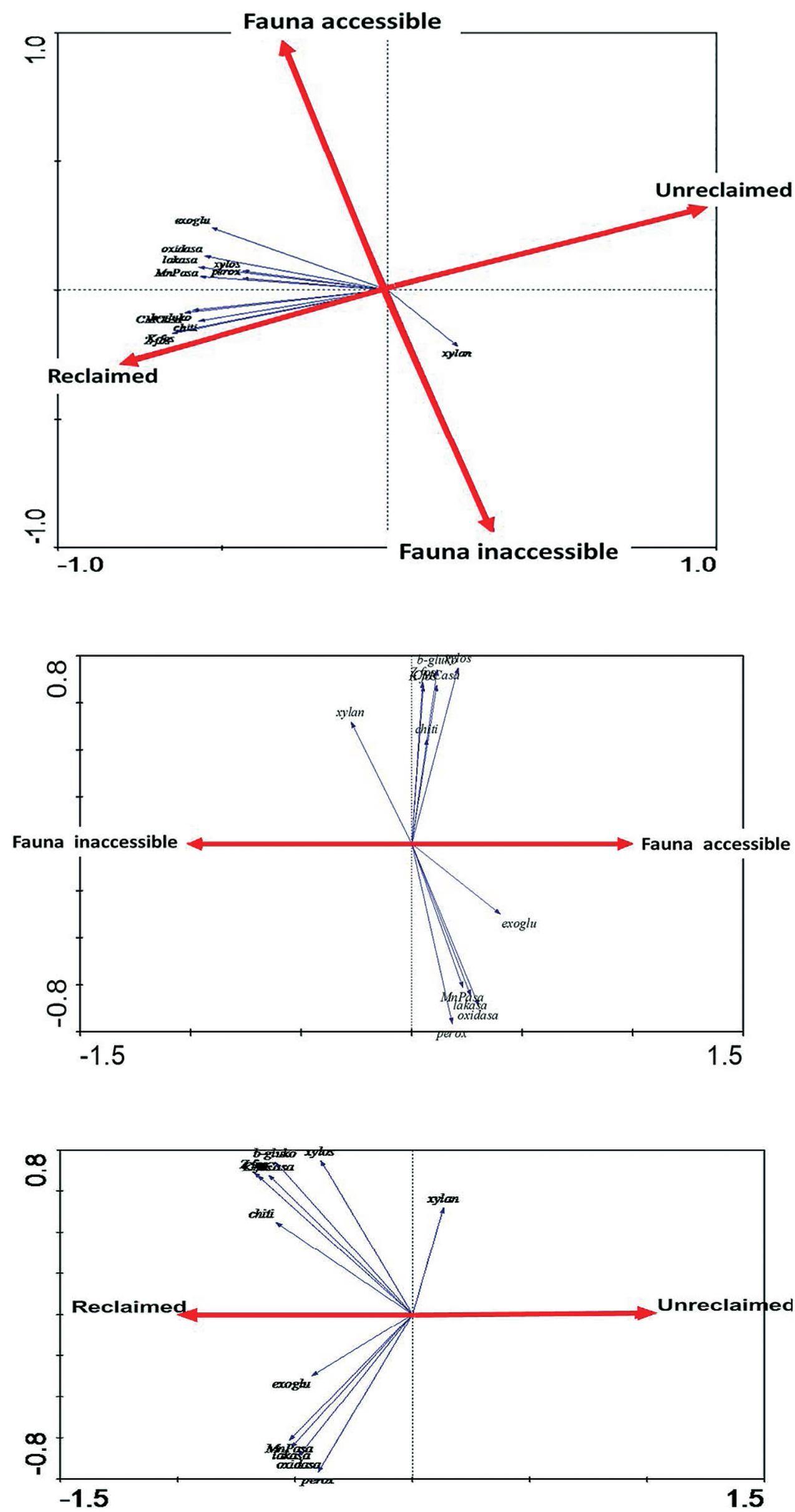


\section{Discussion}

Results of our study did not show any significant differences in enzyme activity between fauna-accessible and fauna-inaccessible mesocosms. We agree that small size of soil microorganisms enables their high dispersal activity in the topsoil layer (Barberán et al., 2014). Our results was supported by study of Baldrian et al. (2008) where the soil fauna did not show any significant effect on fungal biomass expressed as concentration of fungal phospholipid fatty acid (PLFA fungi $)$. Results of our study also corresponded with study of Frouz et al. (2006) where the effects of soil macrofauna on basal soil respiration, microbial biomass and $\mathrm{C}: \mathrm{N}$ ratio in topsoil layer were also not found to be statistically significant. According to Frouz et al. (2006) soil macrofauna significantly affected microbial biomass, basal soil respiration and $\mathrm{C}: \mathrm{N}$ ratio in deeper soil horizon.

Biological activity in topsoil and litter layer is strongly governed by abiotic factors such as soil temperature, $\mathrm{pH}$ and humidity, and biotic factor such as interaction with aboveground biomass (Wardle et al., 2004; Rousk et al., 2010; Zhou et al., 2016). However Crowther et al. (2011) recorded species-specific impact of soil fauna on enzyme activity in laboratory attempts. Wang et al. (2009) found that the loss of biomass in litterbags deposited on Alpine meadows strongly correlated with abundance of oribatids. Frouz (1997) found that microbial activity of litter (expressed as basal soil respiration) significantly increased by adding of bibionid larvae (Bibionidae). These results were discussed in literature (Frouz and Makarova, 2001; Frouz and Simek, 2009) but these studies indicated only short-term effect of soil fauna on biological activity of litter layer.

In other part of our experiment we found that time of the year (season) significantly alters enzyme activity most likely due to climatic factors. Our results corresponded with study of Šnajdr et al. (2008) who found that enzyme activity differed in different seasons (from May 2007 to August 2008). Moreover, this study was supported by study of Baldrian et al. (2008) which was situated at the same study area and in which enzyme activity changed during the season as well. All samples indicated different enzyme activity in different seasons. They found the highest enzyme activity in October 2006. High enzyme activity was caused by high humidity (Wittmann et al., 2004). Effect of seasonality on biological activity of litter (loss of biomass, enzyme activity, decomposition rate and $\mathrm{C}: \mathrm{N}$ ratio) in litter layer was studied in literature (Dilly and Munch, 1996; Fioretto et al., 2000; Wittmann et al., 2004).

In the last part of our study we focused on the effect of reclamation of post-mining sites on enzyme activity in the topsoil layer. Frouz and Nováková (2005) showed significantly higher microbial activity in reclaimed sites than in unreclaimed sites but in successional higher stages, microbial activity among reclaimed and unreclaimed sites was closely related. Frouz et al. (2007) recorded significantly higher abundance of soil meso and macrofauna in reclaimed post-mining sites. Reclaimed sites had higher abundance of endogeic earthworms which supported microbial activity in soil. According to Frouz and Nováková (2005), restoration of post-mining sites supported higher microbial biomass. Microbial biomass may be affected by the type of vegetation cover (Frouz and Nováková, 2005). Georgieva et al. (2005) found that the fungal and bacterial biomass in arable soil were significantly affected by vegetation cover. Sites planted by Viccia villosa showed significantly higher microbial biomass than sites planted by Secale cereale (Georgieva et al., 2005).

\section{Conclusions}

The results of our study did not show any significant effect of soil fauna on the enzyme activity in the litter layer. However, we found a statistically significant effect of time of sampling as well as significant effect of restoration of post-mining sites on enzyme activity in the topsoil layer.

\section{References}

Allison, S.D., and Vitousek, P.M.2005. Responses of extracellular enzymes to simple and complex nutrient inputs. Soil Biology and Biochemistry 37:937-944.

Baldrian, P., Trögl, J., Frouz, J., Šnajdr, J., Valášková, V., Merhautová, V., Cajthaml, T., and Herinková, J. 2008. Enzyme activities and microbial biomass in topsoil layer during spontaneous succession in spoil heaps after brown coal mining. Soil Biology and Biochemistry 40:2107-2115.

Bandick, A. K., and Dick, R.P. 1999. Field management effects on soil enzyme activities. Soil Biology and Biochemistry 31:1471-1479.

Barberán, A., Ramirez, K. S., Leff, J.W., Bradford, M.A., Wall, D.H., and Fierer, N. 2014. Why are some microbes more ubiquitous than others? Predicting the habitat breadth of soil bacteria. Ecology Letters 17:794-802.

Bardgett, R. D., and Cook, R. 1998. Functional aspects of soil animal diversity in agricultural grasslands. Applied Soil Ecology 10:263-276.

Bardgett, R. D., and van der Putten, W. H. 2014. Belowground biodiversity and ecosystem functioning. Nature 515:505-511.

Boddy, L. 1999. Saprotrophic cord-forming fungi: meeting the challenge of heterogeneous environments. Mycologia 91:13-32.

Bradshaw, A. 1997. Restoration of mined lands - using natural processes. Ecological Engineering 8:255-269.

Caldwell, B.A. 2005. Enzyme activities as a component of soil biodiversity: A review. Pedobiologia (Jena). 49:637-644.

Crowther, T. W., Jones, T. H., Boddy, L., and Baldrian, P. 2011. Invertebrate grazing determines enzyme production by basidiomycete fungi. Soil Biology and Biochemistry 43:2060-2068.

Dilly, O., and Munch, J. C. 1996. Microbial biomass content, basal respiration and enzyme activities during the course of decomposition of leaf litter in a black alder (Alnus glutinosa (L) Gaertn) forest. Soil Biology and Biochemistry 28:1073-1081.

Fioretto, A., Papa, S., Curcio, E., Sorrentino, G., and Fuggi, A. 2000. Enzyme dynamics on decomposing leaf litter of Cistus incanus and 
Myrtus communis in a Mediterranean ecosystem. Soil Biology and Biochemistry 32:1847-1855.

Frouz, J.1997. Changes in communities of soil dwelling dipteran larvae during secondary succession in abandoned fields. European Journal of Soil Biology 33:57-65.

Frouz, J., Elhottová, D., Kuráž, V., and Šourková, M. 2006. Effects of soil macrofauna on other soil biota and soil formation in reclaimed and unreclaimed post-mining sites: Results of a field microcosm experiment. Applied Soil Ecology 33:308-320.

Frouz, J., Keplin, B., Pižl, V., Tajovský, K., Starý, J., Lukešová, A., Nováková, A., Balík, V., Háněl, L., Materna, J., Düker, C., Chalupský, J., Rusek, J., and Heinkele, T.2001. Soil biota and upper soil layer development in two contrasting post-mining chronosequences. Ecological Engineering 17:275-284.

Frouz, J., and Makarova, O. L. 2001. Succession of communities of Diptera larvae in decaying fungi. Biologia (Bratisl) 56:191-197.

Frouz, J., and Nováková, A. 2005. Development of soil microbial properties in topsoil layer during spontaneous succession in heaps after brown coal mining in relation to humus microstructure development. Geoderma 129:54-64.

Frouz, J., Pižl, V., and Tajovský, K. 2007. The effect of earthworms and other saprophagous macrofauna on soil microstructure in reclaimed and un-reclaimed post-mining sites in Central Europe. European Journal of Soil Biology 43:S184-S189.

Frouz, J., Roubíčková, A., Heděnec, P., and Tajovský, K. 2015. Do soil fauna really hasten litter decomposition? A meta-analysis of enclosure studies. European Journal of soil Biology 68:18-24.

Frouz, J., and Šimek, M. 2009. Short term and long term effects of bibionid (Diptera: Bibionidae) larvae feeding on microbial respiration and alder litter decomposition. European Journal of Soil Biology 45:192-197.

Georgieva, S., Christensen, S., Petersen, H., Gjelstrup, P., and ThorupKristensen, K. 2005. Early decomposer assemblages of soil organisms in litterbags with vetch and rye roots. Soil Biology and Biochemistry 37:1145-1155.

Heděnec, P., Radochová, P., Nováková, A., Kaneda, S., and Frouz, J. 2013. Grazing preference and utilization of soil fungi by Folsomia candida (Isotomidae:Collembola). European Journal of Soil Biology 55:66-70.

Helingerová, M., Frouz, J., and Šantrůčková, H. 2010. Microbial activity in reclaimed and unreclaimed post-mining sites near Sokolov (Czech Republic). Ecological Engineering 36:768-776.

Lavelle, P.2000. Ecological challenges for soil science. Soil Science 165:73-86.

Lavelle, P., Bignell, D., Lepage, M., Wolters, V., Roger, P., Ineson, P., Heal, O. W., and Dhillion, S. 1997. Soil function in a changing world: the role of invertebrate ecosystem engineers. European Journal of Soil Biology 33:159-193.
Lepš, J., and Hadincová, V. 1992. How reliable are our vegetation analyses? Journal of Vegetation Science 3:119-124.

Pietsch, K.A., Ogle, K., Cornelissen, J. H. C., Cornwell, W. K., Bönisch, G., Craine, J. M., Jackson, B. G., Kattge, J., Peltzer, D. A., Penuelas, J., Reich, P. B., Wardle D. A., Weedon, T., Wright, I. J., Zanne, A. E., and Wirth, C. 2014. Global relationship of wood and leaf litter decomposability: The role of functional traits within and across plant organs. Global Ecology and Biogeography 23:1046-1057.

Rousk, J., Baath, E., Brookes, P.C., Lauber, C.L., Lozupone, C., Caporaso, J. G., Knight, R., and Fierer, N. 2010. Soil bacterial and fungal communities across a pH gradient in an arable soil. ISME Journal 4:1340-1351.

Šnajdr, J., Valášková, V., Merhautová, V., Herinková, J., Cajthaml, T., and Baldrian, P. 2008. Spatial variability of enzyme activities and microbial biomass in the upper layers of Quercus petraea forest soil. Soil Biology and Biochemistry 40:2068-2075.

Tedersoo, L., Bahram, M., Polme, S., Koljalg, U., Yorou, N. S., Wijesundera, R., Villarreal Ruiz, L., Vasco-Palacios, A.M., Thu, P.Q., Suija, A., et al. 2014. Global diversity and geography of soil fungi. Science 346: 1078+.

Valášková, V., Šnajdr, J., Bittner, B., Cajthaml, T., Merhautova, V., Hoffichter, M., and Baldrian, P. 2007. Production of lignocellulose-degrading enzymes and degradation of leaf litter by saprotrophic basidiomycetes isolated from a Quercus petraea forest. Soil Biology and Biochemistry 39:2651-2660.

Vořiššková, J., Dobiášová, P., Šnajdr, J., Vaněk, D., Cajthaml, T., Šantrůčková, H., and Baldrian, P. 2011. Chemical composition of litter affects the growth and enzyme production by the saprotrophic basidiomycete Hypholoma fasciculare. Fungal Ecology 4:417-426.

Wang, S., Ruan, H., and Wang, B. 2009. Effects of soil microarthropods on plant litter decomposition across an elevation gradient in the Wuyi Mountains. Soil Biology and Biochemistry 41:891-897.

Wardle, D.A., Bardgett, R.D., Klironomos, J.N., Setala, H., van der Putten, W. H., and Wall, D.H.2004. Ecological linkages between aboveground and belowground biota. Science 304:1629-1633.

Wardle, D.A., and Lindahl, B. D. 2014. Disentangling global soil fungal diversity. Science 346:1052-1053.

Wells, J. M., and Boddy, L. 2002. Interspecific carbon exchange and cost of interactions between basidiomycete mycelia in soil and wood. Functional Ecology 16:153-161.

Wittmann, C., Kahkonen, M.A., Ilvesniemi, H., Kurola, J., and SalkinojaSalonen, M.S. 2004. Areal activities and stratification of hydrolytic enzymes involved in the biochemical cycles of carbon, nitrogen, sulphur and phosphorus in podsolized boreal forest soils. Soil Biology and Biochemistry 36:425-433.

Zhou, J., Deng, Y., Shen, L., Wen, C., Yan, Q., Ning, D., Qin, Y., Xue, K., $\mathrm{Wu}, \mathrm{L}$., He, Z., et al. 2016. Temperature mediates continental-scale diversity of microbes in forest soils. Nature Communication 7:12083. 